\title{
Glycerol dehydration to hydroxyacetone in gas phase over copper supported on magnesium oxide (hydroxide) fluoride catalysts
}

\author{
Stéphane Célerier, Sophie Morisset, Isabelle Batonneau-Gener, Thomas Belin, Khaled \\ Younes and Catherine Batiot-Dupeyrat ${ }^{*}$
}

IC2MP, UMR CNRS 7285, ENSIP, Université de Poitiers, 1 rue Marcel Doré, 86022 Poitiers,

*Corresponding author: catherine.batiot.dupeyrat@univ-poitiers.fr, Phone: +33549453898,

\begin{abstract}
:
The dehydration of glycerol to hydroxyacetone was studied over copper-based catalysts using magnesium oxide (hydroxide) fluoride with various $\mathrm{F} / \mathrm{Mg}$ ratio as support of copper. After calcination at $350^{\circ} \mathrm{C}$, the incorporation of copper, mainly at + II oxidation state, into the support lattice was observed for $\mathrm{MgO}$ and $\mathrm{MgF}(\mathrm{OH})$ while, copper was stabilized as $\mathrm{Cu}^{+1}$ at the surface of $\mathrm{Cu}-\mathrm{MgF}_{2}$. The reaction of dehydration was performed using a mixture of glycerol and water $\left(80 \%\right.$ wt of glycerol), in gas phase at $260^{\circ} \mathrm{C} . \mathrm{Cu}-\mathrm{MgF}_{2}$ was the most active catalyst with a yield in hydroxyacetone of $45.5 \%$, while the catalytic activity was very low for $\mathrm{Cu}-\mathrm{MgF}(\mathrm{OH})$ and $\mathrm{Cu}-\mathrm{MgO}$ (yield in $\mathrm{HA}<10 \%$ ). Moreover, the performances obtained for $\mathrm{Cu}-\mathrm{MgF}_{2}$ were higher than those obtained with $\mathrm{La}_{2} \mathrm{CuO}_{4}$, a reference catalyst. After four hours of reaction, $\mathrm{Cu}-\mathrm{MgF}_{2}$ was not significantly modified, while for the two other catalysts, $\mathrm{Cu}^{2+}$ initially present was reduced into metallic copper. The results obtained revealed that the basic properties of the catalysts did not govern the reaction of dehydration of glycerol into HA. The best catalyst $\left(\mathrm{Cu}-\mathrm{MgF}_{2}\right)$ was the one possessing the higher amount of Lewis acid sites, and stabilizing copper at +1 oxidation state.
\end{abstract}




\section{Introduction}

Glycerol, the main byproduct obtained from biodiesel industry, is a very promising platform building blocks for fuels and chemicals production [1]. Many applications of glycerol valorization were reported in the literature, such as hydrogenolysis of glycerol to propanediols [2-4], dehydration to acrolein [5-8] and reforming to hydrogen or syngas [9]. Glycerol conversion into acrolein was successfully performed over solid acid catalysts such as heteropoly acids [10] or zeolites [11]. The formation of acrolein is often accompanied by the presence of hydroxyacetone.

Hydroxyacetone (HA) is an interesting chemical product used as flavour in food industry, dyes or additive in cosmetics. It is also an intermediate in the production of valuable compounds such as propyleneglycol, acrolein or propionaldehyde. Therefore there are needs to develop active catalysts to produce selectively HA under mild experimental conditions, in a fixed bed continuous flow process at atmospheric pressure. Indeed, heterogeneous catalytic processes allow to avoid commonly encountered drawbacks of homogeneous catalytic processes including the difficulty of catalysts separation and problems of waste disposal.

Hydroxyacetone can be obtained from glycerol dehydration in gas phase, over catalysts containing Lewis acid sites such as $\mathrm{MOx}-\mathrm{Al}_{2} \mathrm{O}_{3}-\mathrm{PO}_{4}$ [12] or $\mathrm{Zn}-\mathrm{Cr}$ oxides [13] or catalysts containing basic sites such as $\mathrm{NiCo}_{2} \mathrm{O}_{4}$ [14] while over strong Bronsted acid sites the formation of acrolein is favoured [15]. High selectivity to HA was also achieved using the $5 \% \mathrm{Na}$ doped $\mathrm{CeO}_{2}$ basic catalyst at $350^{\circ} \mathrm{C}$, but a poor stability was observed with a rapid deactivation with time on stream [16].

Copper-based catalysts were widely used to perform the hydrogenolysis of glycerol to propanediols due to their lower price and higher resistance to poisoning than noble metals [17]. Copper was also preferred to nickel or cobalt due to its lower activity for C-C bond cleavage. Layered double hydroxide (LDH) supported $\mathrm{Cu}$ catalysts were successfully used in 
the hydrogenolysis of glycerol in aqueous solution, under hydrogen pressure. The high activity was attributed to the strong basicity of the catalyst [18]. For the hydrogenolysis of glycerol, copper is used in its reduced form $\left(\mathrm{Cu}^{\circ}\right)$ in order to favour the hydrogenation step which follows the dehydration one at the surface of the oxide support. Moreover it is also proposed that the $\mathrm{Cu}$ metallic site is involved in the dehydrogenation of glycerol to glyceraldehyde, followed by its dehydration and subsequent hydrogenation to HA [1]. Copper based catalysts were also successfully used without reduction for low temperature glycerol conversion to lactic acid in liquid phase under alkaline conditions [19]. The main drawbacks of the reaction performed in liquid phase are the use of relatively high temperatures and pressures requiring expensive equipments.

In the past decade, metal fluorides and oxide (hydroxide) fluorides prepared by soft chemistry, exhibiting tunable acid-base properties and high specific surface area, have shown promising results in different heterogeneous catalytic processes as active phase or support [20,21]. More specifically, magnesium fluoride was used successfully as support for numerous reactions such as CO oxidation [22], DeNOx [23] synthesis of menthol [24], alkylation of thiophenic compounds [25], synthesis of furfural [26], hydrogenation [27] among others, due to its high thermal and chemical stability. $\mathrm{MgF}_{2}$ is considered as an inert support [28] or as an active support with high density of acid sites with moderate strength [29, 30], depending on the specific surface area and thus, on the synthesis process. Magnesium oxide (hydroxide) fluorides $\mathrm{MgF}_{2-\mathrm{x}} \mathrm{O}_{\mathrm{x} / 2}\left(\right.$ or $\mathrm{MgF}_{2-\mathrm{x}}(\mathrm{OH})_{\mathrm{x}}$ ) or, more specifically, the intimate mixture with controlled composition of $\mathrm{MgO}$ and $\mathrm{MgF}_{2}$, formed after calcination above $400^{\circ} \mathrm{C}$, were also successfully used as support in several applications $[31,32]$. The synthesis and characterization of this new $\mathrm{Mg}-\mathrm{O}-\mathrm{F}$ system and its application as catalytic support were described [33-35]. As an example, $\mathrm{MgF}_{2}-\mathrm{MgO}$ can be considered as a potential support of $\mathrm{NiO}$ in $\mathrm{NOx}$ reduction by propene [33]. The synthesis of the $\mathrm{MgF}_{2}-\mathrm{MgO}$ mesoporous 
material, particularly by sol-gel method [31,36], allows to increase the specific surface area compared to single $\mathrm{MgF}_{2}, \mathrm{MgO}$ or $\mathrm{Mg}(\mathrm{OH})_{2}$ whatever the temperature of calcination [36]. For example, a specific surface area of $644 \mathrm{~m}^{2} \cdot \mathrm{g}^{-1}$ can be obtained for $\mathrm{MgF}(\mathrm{OH})$ before calcination whereas the specific surface area of $\mathrm{MgF}_{2}$ is of $231 \mathrm{~m}^{2} \cdot \mathrm{g}^{-1}$ in the same synthesis conditions. The higher specific surface area favors the high dispersion of the active phase at the surface of the support, leading to high activity in several applications [31-34]. Moreover, the easy control of the F/Mg ratio, by sol-gel process, allows to fine tune the acid-base properties. Indeed, higher the fluorine content, higher the strength of Lewis acidity and lower the amount and strength of basicity [37]. This is obviously due to the stronger inductive effect of fluorine atom in comparison with oxygen atom. The interest of such materials was already demonstrated for Michael addition reactions [38]. Among the different soft chemistry method used to synthesize metal fluorides, the sol-gel method is very promising because it is simple, flexible and cheap, offering an easy control of porosity and microstructural properties [20].

In this work, the selective production of HA from glycerol in gas phase using magnesium oxide (hydroxide) fluoride as support of copper catalyst is reported. To the best of our knowledge, there is no report on the use of such materials for glycerol conversion. A mixture of glycerol and water (80wt \% glycerol) was used while the reaction temperature was fixed at $260^{\circ} \mathrm{C}$. For comparison, a $\mathrm{La}_{2} \mathrm{CuO}_{4}$ catalyst was also evaluated as a reference catalyst, since we showed in a previous study that a high catalytic activity can be reached using pure glycerol (99.9\%) [39]. A correlation between the properties of the materials (acid-base, oxidation state of copper) and HA yield is discussed. 


\section{Experimental}

\section{Catalyst synthesis}

The oxide (hydroxide) fluoride materials used in this work were prepared by a sol-gel method, partly based on the work of Scholz et al. [36]. In a first step, magnesium metal (3.23g, Aldrich, 99,98\%) was treated with methanol in excess (100 mL, Sigma-Aldrich, $99,8 \%)$ under reflux conditions for $6 \mathrm{~h}$ to form a $\mathrm{Mg}\left(\mathrm{OCH}_{3}\right)_{2}$ metal alkoxide solution. For $\mathrm{MgF}_{2}$ support, stoichiometric amount of aqueous $\mathrm{HF}$ (11.074 g, $48 \mathrm{wt} \% \mathrm{HF}$ in water) was added progressively to the solution under stirring (avoiding the formation of a gel). A highly exothermic reaction proceeds leading to the formation of a sol. This sol was stirred for $24 \mathrm{~h}$, aged at ambient temperature for $24 \mathrm{~h}$, and dried at $100^{\circ} \mathrm{C}$ for $24 \mathrm{~h}$, leading to the formation of the powder named $\mathrm{MgF}_{2}$. For the support named $\mathrm{MgF}(\mathrm{OH})$, the protocol was the same except the added amount of HF, which was adjusted to obtain an initial F/Mg ratio of 1. Additional water was used for the hydrolysis of remaining $-\mathrm{OCH}_{3}$ groups, to form hydroxyl group (hydrolysis reaction). For the support named $\mathrm{MgO}$, no $\mathrm{HF}$ was added and the hydrolysis reaction was carried out with an excess of water $\left(6 \mathrm{~g}, \mathrm{H}_{2} \mathrm{O} / \mathrm{Mg}=2.5\right)$. After drying at $100^{\circ} \mathrm{C}$, the materials were calcined at $350^{\circ} \mathrm{C}$ for $5 \mathrm{~h}$ under dry air.

For the impregnation of copper on the support, $2 \mathrm{~g}$ of powder were mixed with a copper acetate solution: $330.5 \mathrm{mg}$ of $\left(\mathrm{CH}_{3} \mathrm{COO}\right)_{2} \mathrm{Cu} .1 \mathrm{H}_{2} \mathrm{O}$ (Aldrich, $\left.98 \%\right)$ dissolved in $17 \mathrm{~mL}$ of water. The amount of copper precursor was adjusted to obtain a theoretical weight content of metallic copper of $5 \%$. This mixture was stirred for $24 \mathrm{~h}$, at ambient temperature and dried at $100^{\circ} \mathrm{C}$ on a sand bath followed by a final drying in a furnace at $80^{\circ} \mathrm{C}$ for $12 \mathrm{~h}$. The catalysts were then calcined at $350^{\circ} \mathrm{C}$, for 5 hours, under dry air to form copper oxide, the materials are named $\mathrm{Cu}-\mathrm{MgO}, \mathrm{Cu}-\mathrm{MgF}(\mathrm{OH})$ and $\mathrm{Cu}-\mathrm{MgF}_{2}$.

In order to compare the performances of these new catalysts with a reference catalyst, $\mathrm{La}_{2} \mathrm{CuO}_{4}$ was also prepared as described in ref [39]. 


\section{Characterization}

XRD analysis of samples were carried out with a PANalytical EMPYREAN powder diffractometer using $\mathrm{CuK}_{\alpha}$ radiation source $\left(\mathrm{K}_{\alpha_{1}}=1.5406 \AA\right.$ and $\left.\mathrm{K}_{\alpha_{2}}=1.5444 \AA\right) . \mathrm{XRD}$ patterns were collected between 15 and $80^{\circ}$ with a $0.033^{\circ}$ step and $300 \mathrm{~s}$ dwell time at each step. The identification of the phases was performed with the HighScorePlus software (PANalytical@) and by comparison with the ICDD database reference files.

Nitrogen adsorption was performed at $-196^{\circ} \mathrm{C}$ using a TRISTAR 3000 gas adsorption system. Prior $\mathrm{N}_{2}$ adsorption, the powder samples were degassed under secondary vacuum for $12 \mathrm{~h}$ at $250^{\circ} \mathrm{C}$. The BET equation was used to calculate the surface area of the samples $\left(\mathrm{S}_{\mathrm{BET}}\right.$ in $\mathrm{m}^{2} \cdot \mathrm{g}^{-}$ ${ }^{1}$ ). The total pore volume was calculated from the adsorbed volume of nitrogen at $\mathrm{P} / \mathrm{P}_{0}$ equal to 0.99 . The average mesopore-size distribution was calculated from the desorption isotherm branch using the Barret-Joyner-Halenda (BJH) method.

The magnesium and copper contents of the samples were determined by Inductively Coupled Plasma-Optical Emission Spectrometry (ICP OES) using a PerkinElmer Optima 2000DV instrument.

The amount of carbon deposition, after the catalytic test, was calculated by Thermogravimetric analysis (TGA) using a Q600TA Instrument apparatus, under dry air, with a heating rate of $5^{\circ} \mathrm{C} \min ^{-1}$ from room temperature to $900^{\circ} \mathrm{C}$.

The acidity of solid materials was measured by adsorption of pyridine followed by FT-IR spectroscopy, using a ThermoNicolet NEXUS 5700 spectrometer with a resolution of $2 \mathrm{~cm}^{-1}$ and 128 scans per spectrum. The samples were pressed into thin pellets $(10-30 \mathrm{mg})$ with diameter of $16 \mathrm{~mm}$ under a pressure of $1-2{\mathrm{t} . \mathrm{cm}^{-2}}$ and activated in situ during one night under vacuum $\left(10^{-5} \mathrm{~Pa}\right)$ at $250^{\circ} \mathrm{C}$. Pyridine was introduced in excess, at $150^{\circ} \mathrm{C}$, after the activation period. The solid sample was vacuum-packed to eliminate physisorbed pyridine and IR spectrum was recorded at $150^{\circ} \mathrm{C}$. The concentration of Lewis acid sites was determined from 
the integrated area band located between 1445 and $1455 \mathrm{~cm}^{-1}$, using $1.28 \mathrm{~cm} . \mu \mathrm{mol}^{-1}$ as molar extinction coefficient. Note that no Bronsted acid site was detected by this method on all samples (no band observed between 1540 and $1550 \mathrm{~cm}^{-1}$ ).

Temperature programmed reduction analysis (TPR) were carried out in a Micromeritics Autochem 2910 equipment using $100 \mathrm{mg}$ of catalyst. The experiments were performed using a $5 \% \mathrm{H}_{2} / \mathrm{Ar}$ mixture, with a flow rate of $100 \mathrm{~mL} \cdot \mathrm{min}^{-1}$, while the temperature was raised at $5{ }^{\circ} \mathrm{C} \min ^{-1}$ from ambient to $900{ }^{\circ} \mathrm{C}$, then maintained at this temperature for $30 \mathrm{~min}$. Prior to the measurements, the samples were outgassed under helium at $350{ }^{\circ} \mathrm{C}$ for $8 \mathrm{~h}$.

$\mathrm{CO}_{2}$ adsorption experiments were performed to determine the basic properties of the catalysts. Adsorption equilibrium data were measured thermogravimetrically at $298 \mathrm{~K}$ using a symmetrical SETARAM microbalance. A weight of 10 to $15 \mathrm{mg}$ of sample was outgassed under secondary vacuum at $573 \mathrm{~K}$ for 6 hours and then cooled down to $298 \mathrm{~K}$ prior to the sorption measurements. The temperature of the system is kept constant during analysis by a water circulation in the double wall of the analysis tube. The $\mathrm{CO}_{2}$ pressure was then increased step by step in order to obtain the entire adsorption isotherm. For each uptake, the equilibrium was reached when the mass recorded versus time and the pressure were stable.

The XPS analysis were carried out with a Kratos Axis Ultra DLD spectrometer using a monochromatic $\mathrm{Al} \mathrm{K} \alpha$ source $(10 \mathrm{~mA}, 15 \mathrm{kV})$. The charge Neutraliser system was operated for all analysis. Instrument base pressure was $9 \times 10^{-8}$ Pascal. High-resolution spectra were recorded using an analysis area of $300 \mu \mathrm{m} \times 700 \mu \mathrm{m}$ and a $40 \mathrm{eV}$ pass energy. These pass energies correspond to Ag 3d5/2 FWHM of $0.55 \mathrm{eV}$. Data were acquired with $0.1 \mathrm{eV}$ steps. All the binding energies were calibrated with the $\mathrm{Mg} 2 \mathrm{p}$ binding energy fixed at $50.7 \mathrm{eV}$ as an internal reference. 


\section{Catalytic activity}

The reaction was performed using a mixture of glycerol and water (80\%wt of glycerol) with a liquid flow rate of $0.04 \mathrm{~mL} \cdot \mathrm{min}^{-1}$. The reactor was a quartz tube of $13 \mathrm{~mm}$ i.d. and 400mm length. The catalytic decomposition of glycerol was carried out at atmospheric pressure by passing a continuous flow of $20 \% \mathrm{v} / \mathrm{v}$ glycerol solution in $\mathrm{N}_{2}$ as the carrier gas over the catalyst bed (200mg). The Gas Hourly Space velocity was equal to $13.5 \mathrm{~L} \cdot \mathrm{h}^{-1} \cdot \mathrm{g}^{-1}$. A two zone reactor was used, glycerol being vaporized in the first empty zone before arriving to the reaction zone.

The temperature in the first reactor was maintained at $300^{\circ} \mathrm{C}$, while the temperature in the second reactor was fixed at $260^{\circ} \mathrm{C}$. Liquid phase products were recovered by condensation in two cold traps located at the reactor outlet for further analysis, whereas gas phase was analyzed by gas chromatography during the reaction. We checked that under the experimental conditions used (relatively low temperature) no significant gaseous products such as carbon monoxide or carbon dioxide was produced. Separation and quantification of main organic compounds in liquid phase were performed using a gas chromatograph (Varian $430 \mathrm{GC}$ ) equipped with a capillary column $(50 \mathrm{~m} \times 0.25 \mathrm{~mm} \times 0.2 \mu \mathrm{m}, \mathrm{CP}$ WAX $58 \mathrm{CB})$ and a FID detector. Quantification was performed by using butanol as internal standard. The products of the glycerol decomposition were identified by GC-MS (Varian 3800, injector 1079) coupled with a mass spectrometer (Analyser triple quadrupole Varian 1200L with an electric impact source of $70 \mathrm{eV})$.

Conversion of glycerol and selectivity to hydroxyacetone was calculated according to the following equations:

Glycerol conversion $(\%)=\frac{\text { mol of glycerol reacted }}{\text { mol of glycerol in the feed }} \times 100$ Selectivity to hydroxyacetone $(\%)=\frac{\text { mol of hydroxyacetone produced }}{\text { mol of glycerol transformed }} \times 100$ 


\section{Results and discussion}

\section{Synthesis and characterization of the catalysts}

The different magnesium oxide (hydroxide) fluorides were prepared according to a solgel method, from a metal alkoxide precursor, in an aqueous HF solution. Briefly, a competition between fluorolysis (reaction with HF) and hydrolysis (reaction with water) occurs, resulting in the formation of $\mathrm{MgF}_{2-\mathrm{x}}(\mathrm{OH})_{\mathrm{x}}$ as described in ref [36]. Kinetically, the fluorolysis rate is higher than the hydrolysis rate, allowing a partial control of the composition. As reported previously, with an equivalent method [36], the final F/Mg ratio (2x) corresponds approximately to the initial $\mathrm{HF} / \mathrm{Mg}$ ratio. The remaining $-\mathrm{OCH}_{3}$ groups of the magnesium alkoxide react with water forming the hydroxyl groups of the hydroxide fluorides. Based on previous works [36], materials with a composition closed to $\operatorname{MgF}_{2}(\mathrm{x}=0)$, $\operatorname{MgF}(\mathrm{OH})(\mathrm{x}=1)$ and $\mathrm{Mg}(\mathrm{OH})_{2}(\mathrm{x}=2)$ were synthesized with an initial $\mathrm{HF} / \mathrm{Mg}$ ratios of 2, 1 and 0 respectively. Thus, the fluorine content in the magnesium hydroxide fluoride is easily tuned thanks to the amount of HF added [31].

The X-ray diffraction (XRD) patterns of $\mathrm{Cu}-\mathrm{MgO}, \mathrm{Cu}-\mathrm{MgF}(\mathrm{OH})$ and $\mathrm{Cu}-\mathrm{MgF}_{2}$ obtained after copper impregnation on the magnesium oxide hydroxide fluoride supports, and after calcination at $350^{\circ} \mathrm{C}$ are reported in Figure 1 . The calcination temperature was chosen in order to stabilize thermally the catalysts while the reaction was performed at $260^{\circ} \mathrm{C} . \mathrm{MgO}$ (card $\mathrm{n}^{\circ} 01-089-7746$ of the ICDD database), $\mathrm{MgF}_{2}$ (card $\left.\mathrm{n}^{\circ} 98-009-4270\right)$ and a mixture of $\mathrm{Mg}(\mathrm{OH})_{2}\left(\right.$ card $\left.\mathrm{n}^{\circ} 01-075-1527\right)$ and $\mathrm{MgF}_{2}$ are mainly observed on the samples $\mathrm{Cu}-\mathrm{MgO}, \mathrm{Cu}-$ $\mathrm{MgF}_{2}$ and $\mathrm{Cu}-\mathrm{MgF}(\mathrm{OH})$ respectively. Interestingly, $\mathrm{MgO}$ in $\mathrm{Cu}-\mathrm{MgO}$ and $\mathrm{MgF}_{2}$ in $\mathrm{Cu}-\mathrm{MgF}_{2}$ are well crystallized whereas a low degree of crystallinity is observed for $\mathrm{Cu}-\mathrm{MgF}(\mathrm{OH})$. Indeed, the presence of two phases affects the rate of crystallization of both phases as observed by Wojciechowska et al. [23]. In our experimental conditions, the method used does 
not lead to the formation of a magnesium oxide (hydroxide) fluoride but to an intimate mixture of magnesium oxide (or hydroxide in our case) and fluoride as already observed in previous works [23]. The formation of $\mathrm{CuO}$ (card $\left.\mathrm{n}^{\circ} 00-041-0254\right)$ with the main diffraction peaks at 35.5 and $38.8^{\circ}$ and $\mathrm{Cu}_{2} \mathrm{O}$ (card $\left.\mathrm{n}^{\circ} 98-005-2043\right)$ with the main diffraction peaks at 36.4 and $42.3^{\circ}$ are clearly observed for $\mathrm{Cu}-\mathrm{MgO}$ and $\mathrm{Cu}-\mathrm{MgF}_{2}$ respectively. Nevertheless, the presence of $\mathrm{CuO}$ on $\mathrm{Cu}-\mathrm{MgF}_{2}$ and $\mathrm{Cu}_{2} \mathrm{O}$ on $\mathrm{Cu}-\mathrm{MgO}$ cannot be totally excluded due to the overlapping of copper oxide with the peaks of the support. The attribution of the copper phase is more difficult in the case of $\mathrm{Cu}-\mathrm{MgF}(\mathrm{OH})$. Only one peak at 36.1 can be attributed to copper oxide phase. Nevertheless, this broad peak with low intensity, characteristic of poorly crystallized phase, can be attributed to (111) peak of $\mathrm{CuO}$ as well as (111) peak of $\mathrm{Cu}_{2} \mathrm{O}$ since the other main peaks of these phases can be overlapped with the broad peaks of $\operatorname{Mg}(\mathrm{OH})_{2}$ and/or $\mathrm{MgF}_{2}$.

Finally, due to the low intensity of copper phases on XRD patterns, the determination of the crystallite size of copper oxide is difficult. Nevertheless, the higher intensity and thinner peaks of $\mathrm{Cu}_{2} \mathrm{O}$ in $\mathrm{Cu}-\mathrm{MgF}_{2}$ is characteristic of larger crystallites in comparison with copper oxides in $\mathrm{Cu}-\mathrm{MgO}$ and $\mathrm{Cu}-\mathrm{MgF}(\mathrm{OH})$.

The copper contents determined by ICP OES analysis (Table 1) are closed to the desired theoretical content (5\%) indicating that the chosen synthesis method is well adapted to control the copper content.

The specific surface areas of the samples are reported in Table 1. As observed, after calcination at $350^{\circ} \mathrm{C}$ and before impregnation of copper, the $\mathrm{MgF}(\mathrm{OH})$ support possesses a very high specific surface area $\left(270 \mathrm{~m}^{2} \cdot \mathrm{g}^{-1}\right)$, higher than the $\mathrm{S}_{\mathrm{BET}}$ of $\mathrm{MgO}\left(227 \mathrm{~m}^{2} \cdot \mathrm{g}^{-1}\right)$ and especially the $\mathrm{S}_{\mathrm{BET}}$ of $\mathrm{MgF}_{2}\left(33 \mathrm{~m}^{2} \cdot \mathrm{g}^{-1}\right)$. This result confirms that the synthesis of magnesium oxide (hydroxide) fluoride (or the intimate mixture of $\mathrm{MgF}_{2}$ and $\mathrm{Mg}(\mathrm{OH})_{2}$ in our case) by solgel method, improves the specific surface area compared to $\mathrm{MgF}_{2}$ and $\mathrm{MgO}$ alone. This can 
be attributed to the low rate of crystallinity of this sample as discussed above. The adsorptiondesorption isotherms of all solids are shown in Fig. S1 (see supplementary information). A type IV isotherm according to the IUPAC classification was observed for all samples, whatever the fluorine content, showing the formation of mesoporous solids with high value of porous volume (Table S1). The porous volume decreases with the increase of fluorine content. The average pore size is significantly smaller for the $\operatorname{MgF}(\mathrm{OH})$ support in comparison with $\mathrm{MgF}_{2}$ and $\mathrm{MgO}$.

After impregnation of copper and calcination at $350^{\circ} \mathrm{C}$, the specific surface area decreases for $\mathrm{Cu}-\mathrm{MgF}(\mathrm{OH})$ from 270 to $165 \mathrm{~m}^{2} \cdot \mathrm{g}^{-1}$ and for $\mathrm{Cu}-\mathrm{MgO}$ from 227 to $68 \mathrm{~m}^{2} \cdot \mathrm{g}^{-1}$, whereas it remains stable for $\mathrm{Cu}-\mathrm{MgF}_{2}$ with $33 \mathrm{~m}^{2} \mathrm{~g}^{-1}$ before and $36 \mathrm{~m}^{2 \cdot} \mathrm{g}^{-1}$ after copper impregnation and calcination. A type IV isotherm is retained for the three catalysts (Fig S1), the pore volume decreases for $\mathrm{Cu}-\mathrm{MgF}(\mathrm{OH})$ and for $\mathrm{Cu}-\mathrm{MgO}$ in comparison with the supports without copper, which is in accordance with the changes of specific surface area. The average pore sizes are retained before and after copper impregnation and calcination (table S1). The decrease of the specific surface area can be attributed to the impregnation step performed in water, with a probable hydrolysis of the remaining $-\mathrm{OCH}_{3}$ due to the incomplete fluorination/hydrolysis of the methanolic $\mathrm{Mg}\left(\mathrm{OCH}_{3}\right)_{2}$ solution [40]. Indeed, the higher the content of the remaining -OR in the magnesium oxide (hydroxide) fluoride, the larger the surface. Nevertheless, very high specific surface area is obtained for $\mathrm{Cu}-\mathrm{MgF}(\mathrm{OH})$ compared to the two other samples which is in accordance with the low rate of crystallinity observed by XRD (Fig. 1).

The determination of the acidity of the catalysts was performed by adsorption of pyridine followed by FT-IR spectroscopy and the results are reported in Table 1 and fig S2. A deeper discussion is also reported in section 2 of the supplementary information concerning the experiments. Note that the characterization of the acidity of $\mathrm{La}_{2} \mathrm{CuO}_{4}$ catalyst was not possible due to the too low surface area of the catalyst $\left(\mathrm{S}_{\mathrm{BET}}=2.2 \mathrm{~m}^{2} \cdot \mathrm{g}^{-1}\right)$, that did not allow 
the quantification of acid sites. No significant amount of Lewis acid site is observed on $\mathrm{Cu}-$ $\mathrm{MgO}$ and $\mathrm{Cu}-\mathrm{MgF}(\mathrm{OH})$ by this method. On the contrary, a significant amount of Lewis acid sites $\left(50 \mu \mathrm{mol} \mathrm{g}^{-1}\right)$ is determined on $\mathrm{Cu}-\mathrm{MgF}_{2}$. Interestingly, this value is closed to the amount observed on the support alone prepared at $350^{\circ} \mathrm{C}\left(48 \mu \mathrm{mol} \mathrm{g}{ }^{-1}\right)$ showing that the presence of copper does not change significantly the acidity of the material (section 2 of supplementary information). This could be explained by the replacement of a Lewis acid site of $\mathrm{MgF}_{2}$ by copper ion (+1), which acts as an electron acceptor providing Lewis acid centers [40]. However, it is also possible to propose that the Lewis acidity would result mainly from the support since $\mathrm{Cu}^{+1}$ is present as large particles at the surface of the support (according to XRD). Moreover, it is also possible that the Lewis acid sites of $\mathrm{Cu}^{+1}$ are not enough strong to react with pyridine.

Furthermore, it is well known that the strength of Lewis acid sites of $\mathrm{MgF}_{2}$ is moderate [29]. For the supports $\mathrm{MgO}$ and $\mathrm{MgF}(\mathrm{OH})$, exhibiting no significant amount of Lewis acid sites (but basic properties, as discussed below), the introduction of copper did not enhance the number of Lewis acid site. The low acidity of $\mathrm{CuOx}-\mathrm{MgO}$ catalysts was proved by Popescu et al. [41]. It could also be explained by the diffusion of copper into the basic support as shown by XPS (see below). Surprisingly, no Lewis acid sites are observed on $\mathrm{Cu}-\mathrm{MgF}(\mathrm{OH})$ whereas $\mathrm{MgF}_{2}$ is present in this sample (as shown by XRD). This can be explained by the formation of an intimate mixture of $\mathrm{MgF}_{2}$ and $\mathrm{Mg}(\mathrm{OH})_{2}$ leading to strong interactions between both phases. The presence of hydroxyl groups $\left(\mathrm{Mg}(\mathrm{OH})_{2}\right)$ in the vicinity of unsaturated magnesium Lewis acid sites $\left(\mathrm{MgF}_{2}\right)$ decreases probably the strength of Lewis acidity due to the lower inductive effect of $-\mathrm{OH}$ in comparison with fluorine atom. Consequently, the Lewis acid sites of $\mathrm{Cu}-\mathrm{MgF}(\mathrm{OH})$ are not enough strong to react with pyridine, a strong base.

TPR analysis 
The TPR profiles of the catalysts $\mathrm{Cu}-\mathrm{MgO}, \mathrm{Cu}-\mathrm{MgF}(\mathrm{OH})$ and $\mathrm{Cu}-\mathrm{MgF}{ }_{2}$ are reported in Fig. 2.

The reduction profile of $\mathrm{Cu}-\mathrm{MgO}$ shows two broad peaks in the $250-500^{\circ} \mathrm{C}$ temperature range, which is in accordance with the results reported by Reddy et al. [42]. The first reduction peak can be attributed to the reduction of well distributed $\mathrm{CuO}$ species or small copper oxide clusters interacting weakly with the support, and the second reduction peak, at higher temperature can be associated to large $\mathrm{CuO}$ particles or aggregated $\mathrm{CuO}$ clusters $[42$, 43]. Moreover, the reduction of $\mathrm{CuO}$ in two steps was also proposed $\left(\mathrm{CuO} \rightarrow \mathrm{Cu}_{2} \mathrm{O} \rightarrow \mathrm{Cu}^{\circ}\right)$ [41].

The reduction of $\mathrm{Cu}-\mathrm{MgF}_{2}$ proceeds at low temperature $\left(225^{\circ} \mathrm{C}\right)$ as a single peak, however the non-gaussian profile of the peak suggests that different copper oxide species are present. As shown in Fig. 1, $\mathrm{Cu}_{2} \mathrm{O}$ particles are observed in $\mathrm{Cu}-\mathrm{MgF}_{2}$. According to previous studies, $\mathrm{CuO}$ is more easily reduced than $\mathrm{Cu}_{2} \mathrm{O}$, which seems in contradiction with the present study $[44,45]$ by example the reduction peak of $\mathrm{CuO} / \mathrm{SiC}$ is centered at $287^{\circ} \mathrm{C}$ against $302^{\circ} \mathrm{C}$ for $\mathrm{Cu}_{2} \mathrm{O} / \mathrm{SiC}$ [44]. However the reduction temperature depends strongly on the nature of copper support. The reduction of $\mathrm{Cu}_{2} \mathrm{O}$ at a temperature as low as $225^{\circ} \mathrm{C}$ was reported by different authors over $\mathrm{TiO}_{2}[46,47]$. It was also shown that the reduction temperature depends strongly on phase structures: the $\mathrm{Cu}_{2} \mathrm{O}$-rutile $\mathrm{TiO}_{2}$ interaction was much stronger than the $\mathrm{Cu}_{2} \mathrm{O}$ anatase $\mathrm{TiO}_{2}$ interaction. In our case, weak $\mathrm{Cu}_{2} \mathrm{O}$ interaction was observed with $\mathrm{MgF}_{2}$ possessing the biggest particles and lower specific surface area.

The amount of $\mathrm{H}_{2}$ consumed is reported in Table 2 for each catalyst. It can be observed that the hydrogen consumption for the reduction of $\mathrm{Cu}-\mathrm{MgO}$ is significantly higher than that for the reduction of $\mathrm{Cu}-\mathrm{MgF}(\mathrm{OH})$ and $\mathrm{Cu}-\mathrm{MgF}_{2}$. Assuming that the hydrogen consumption corresponds to copper oxide reduction, the amount of copper at the oxidation state of +2 and +1 can be calculated according to the following reactions: 
$\mathrm{CuO}+\mathrm{H}_{2}=\mathrm{Cu}+\mathrm{H}_{2} \mathrm{O}$

$\mathrm{Cu}_{2} \mathrm{O}+\mathrm{H}_{2}=2 \mathrm{Cu}+\mathrm{H}_{2} \mathrm{O}$

The results show that $\mathrm{Cu}^{2+}$ is mainly obtained on $\mathrm{MgO}$ while $\mathrm{Cu}^{1+}$ is the major copper species formed over $\mathrm{MgF}_{2}$. This is in agreement with the characterizations by XRD exhibiting the presence of $\mathrm{Cu}_{2} \mathrm{O}$ in $\mathrm{Cu}-\mathrm{MgF}_{2}$ and $\mathrm{CuO}$ in $\mathrm{Cu}-\mathrm{MgO}$. Thus, $\mathrm{MgF}_{2}$, the more acidic support, stabilized copper species at +1 oxidation step, while a mixture of $\mathrm{Cu}^{2+}$ and $\mathrm{Cu}^{+}$is obtained for $\mathrm{MgF}(\mathrm{OH})$. Obtaining a mixture of $\mathrm{Cu}^{2+}$ and $\mathrm{Cu}^{1+}$ for this last catalyst is not surprising since the support is composed of two intimately mixed phases $\left(\mathrm{MgF}_{2}\right.$ and $\left.\mathrm{Mg}(\mathrm{OH})_{2}\right)$, each phase stabilizing $\mathrm{Cu}^{+}$and $\mathrm{Cu}^{2+}$ respectively.

$\mathrm{CO}_{2}$ adsorption isotherms for $\mathrm{Cu}-\mathrm{MgO}, \mathrm{Cu}-\mathrm{MgFOH}$ and $\mathrm{Cu}-\mathrm{MgF}_{2}$ are used to characterize the basicity and are presented in figure 3. From the observed results, it appears that the material basicity is not linked to the copper content since the materials exhibit very different $\mathrm{CO}_{2}$ adsorption behaviors. The total $\mathrm{CO}_{2}$ adsorption capacity depends on the material porosity whereas the amount of $\mathrm{CO}_{2}$ adsorbed in the monolayer is directly linked to the basic site number present at the material surface. So, these isotherms have been analyzed using the BET model. As expected, the calculated amount of $\mathrm{CO}_{2}$ adsorbed in the monolayer is linked to the material BET surface area determined by nitrogen physisorption (figure 4). The more important the surface area is, the higher is the $\mathrm{CO}_{2}$ amount directly in interaction with the solid surface. From these result, it appears that the $\mathrm{Cu}-\mathrm{MgFOH}$ sample has the higher basic site amount and $\mathrm{Cu}-\mathrm{MgF}_{2}$ the lowest.

XPS analysis

The surface composition of the catalysts were determined by XPS analysis and the $\mathrm{Cu} / \mathrm{Mg}$ atomic ratio was calculated. As shown in Table 3, the $\mathrm{Cu} / \mathrm{Mg}$ ratio is higher at the surface of the $\mathrm{MgF}_{2}$ support than in the bulk. In contrast, an important enrichment of $\mathrm{Mg}$ at 
the surface of $\mathrm{MgF}(\mathrm{OH})$ and $\mathrm{MgO}$ is observed. The occupation of the catalyst surface by $\mathrm{Mg}$ was evidenced by Liu et al. studying a $\mathrm{CuO}-\mathrm{MgO}-\mathrm{TiO}_{2}$ catalyst [48]. So, with $\mathrm{MgF}(\mathrm{OH})$ and $\mathrm{MgO}$ as support, copper is incorporated into the support lattice leading to a higher $\mathrm{Cu}-\mathrm{Mg}$ interaction, which corroborates the TPR profiles. Using $\mathrm{MgF}_{2}$ as support, the diffusion of copper into the bulk is not favored, the metal-support interaction is lower explaining the lower reduction temperature (see Fig. 2).

$\mathrm{Cu} 2 \mathrm{p} 3 / 2 \mathrm{XPS}$ spectra of the catalysts $\mathrm{Cu}-\mathrm{MgO}, \mathrm{Cu}-\mathrm{MgFOH}$ and $\mathrm{Cu}-\mathrm{MgF}_{2}$ are shown in Figure 5. For the $\mathrm{Cu}-\mathrm{MgO}$ catalyst, the presence of $\mathrm{Cu}^{2+}$ species is observed thanks to the presence of the satellites peaks (BE region between $938 \mathrm{eV}$ and $944 \mathrm{eV}$ ) which is the fingerprint of $\mathrm{Cu}^{2+}$ oxidation state. However the binding energy corresponding to $\mathrm{Cu} 2 \mathrm{p} 3 / 2$ is observed at $932.9 \mathrm{eV}$, a value significantly lower than the expected one: $933.6 \mathrm{eV}$ [49] probably due a charge transfer from the metal ion toward the support matrix.

For $\mathrm{Cu}-\mathrm{MgFOH}$, two $\mathrm{Cu}$ species seem to be present, one with a $\mathrm{Cu} 2 \mathrm{p} 3 / 2$ binding energy of $932.8 \mathrm{eV}$ and the other with a $\mathrm{Cu} 2 \mathrm{p} 3 / 2$ binding energy of $936.1 \mathrm{eV}$. These are consistent with $\mathrm{Cu}$ (II) species and the latter is consistent with $\mathrm{Cu}(\mathrm{OH})_{2}$ as proposed by Frost et al. [50]. Nevertheless the presence of $\mathrm{CuF}_{2}$ cannot be excluded since fluoride atom are present in the support and can react with copper species. The formation of such species would confirm the reaction between copper and the support during the calcination step.

For the $\mathrm{Cu}-\mathrm{MgF}_{2}$ sample a single and intense peak centered at $932.1 \mathrm{eV}$ is visible, while no satellite peaks are observed indicating that there is no $\mathrm{Cu}^{2+}$ but the presence of reduced copper species. As it is well known, XPS cannot differentiate between $\mathrm{Cu}^{0}$ and $\mathrm{Cu}^{+}$since the binding energy is similar. However, the presence of $\mathrm{Cu}^{0}$ is unlikely in the present study since the catalyst was calcined at $350^{\circ} \mathrm{C}$ under air and no metallic copper are observed by XRD.

The XPS analysis are in accordance with the results obtained by XRD and TPR, showing the presence of $\mathrm{Cu}^{+}$with $\mathrm{MgF}_{2}$ used as support, while $\mathrm{Cu}^{2+}$ is formed on $\mathrm{MgO}$. Moreover, 
significant higher amount of copper is observed at the surface of $\mathrm{MgF}_{2}$ compared to both other catalysts.

Consequently the combination of characterization methods (TPD, XRD, TPR, XPS), proves that copper is obtained at different oxidation state depending on the nature of the support. However it is not possible to propose a simple correlation between oxidation state of copper and support physico-chemical properties since the three materials differ strongly in terms of acid/base properties, fluorine content, size of particles...

\section{Catalytic results}

The reaction was investigated in gas phase using a mixture of glycerol and water ( $80 \mathrm{wt}$ $\%$ glycerol) at $260^{\circ} \mathrm{C}$ to avoid the production of gaseous products at higher temperatures. The main product was HA but pyruvaldehyde and glyceraldehyde were also formed. Other products were analysed but they were present in low amount: propionaldehyde, glycidol, 1,3 propanediol, 1 propanol...

First, using the support alone (without copper) it was confirmed that no glycerol transformation occurs, indicating the crucial role of copper.

The catalytic activity of the copper supported on oxide (hydroxide) fluoride catalysts is compared with $\mathrm{La}_{2} \mathrm{CuO}_{4}$, which exhibited a high activity toward glycerol dehydration into hydroxyacetone in the absence of water in the gas feed [39]. The catalytic behavior of the three oxide (hydroxide) fluoride based catalysts differs strongly. The highest glycerol conversion is obtained over the $\mathrm{Cu}-\mathrm{MgF}_{2}$ catalyst, it reaches $82 \%$ and remains relatively stable during four hours of reaction (figure 6). $\mathrm{Cu}-\mathrm{MgO}$ and $\mathrm{Cu}-\mathrm{MgFOH}$ are little active under our experimental conditions with a glycerol conversion of $19 \%$ and $33 \%$ after one hour of reaction respectively. The yield in $\mathrm{HA}$ is also maximum with $\mathrm{Cu}-\mathrm{MgF}_{2}$, decreasing 
slightly with time on stream (figure 7). Moreover, the $\mathrm{Cu}-\mathrm{MgF}_{2}$ catalyst is significantly more active than $\mathrm{La}_{2} \mathrm{CuO}_{4}$, in the presence of water.

High glycerol conversions were also reported by Carvalho et al. [51] using Cu-based hydroyapatites. The authors showed that glycerol conversion increased with the amount of copper (from 3 to $17 \%$ ) highlighting the crucial role of copper as in the present work. However a catalytic deactivation is observed after few hours on stream. Sato et al. [52] studied the influence of the support on glycerol conversion over copper-based catalysts in gas phase at $250^{\circ} \mathrm{C}$, they found that the acid-base property of the support affected the selectivity: basic $\mathrm{MgO}, \mathrm{CeO}_{2}$ and $\mathrm{ZnO}$ supports showed low selectivity to hydroxyacetone, while acidic supports such as $\mathrm{Al}_{2} \mathrm{O}_{3}, \mathrm{ZrO}_{2}, \mathrm{Fe}_{2} \mathrm{O}_{3}$ and $\mathrm{SiO}_{2}$ promoted $\mathrm{HA}$ selectivity which is in accordance with our results $\left(\mathrm{Cu}-\mathrm{MgF}_{2}\right.$ being the most acidic catalyst).

Glycerol dehydration into hydroxyacetone implies the removal of one of the two $\mathrm{OH}$ groups from the terminal carbons in the glycerol molecule, while the removal of the $\mathrm{OH}$ group from the central carbon atom leads to the formation of acrolein through the unstable 3hydroxypropenal. The predominant route depends mainly on the nature of the acid sites, it has been suggested that acrolein is formed over Brønsted acid sites and hydroxyacetone over Lewis acid sites [53]. The role of basic centers was also proposed by Stosic et al. [53]. The authors showed that the yield in HA was increased with the number of basic sites. However, using hydroxyapatite catalyst, the main reaction product was acrolein, they concluded that acrolein formation was not only controlled by the surface acidity but also by hindering the number/strength/activity of the basic sites, and thus limiting the side reactions which affect the selectivity in acrolein. An intermediate enol is suggested to be formed at the surface of basic centers, afterwards the enol is rapidly transformed by rearrangement into 1hydroxyacetone. The results obtained in the present study showed that the basic properties of the catalysts does not governed the dehydration of glycerol into HA but that HA is 
preferentially produced over the catalyst possessing Lewis acidity $\left(\mathrm{Cu}-\mathrm{MgF}_{2}\right)$, while no acrolein was formed. The high yield in HA can be directly correlated with the amount of $\mathrm{Cu}^{+1}$, which also corresponds to the maximum number of Lewis acid sites (figure 8). Moreover, the Lewis acid sites of the $\mathrm{MgF}_{2}$ support are not able to convert glycerol into hydroxyacetone since no activity was observed with $\mathrm{MgF}_{2}$ alone. Mitta et al. [40] also showed that a Y zeolite possessing $180 \mu \mathrm{mol} \mathrm{g} \mathrm{g}^{-1}$ of Lewis acid sites exhibited a very low glycerol conversion without copper. It is thus possible to conclude that the dehydration of glycerol requires the presence of copper under the experimental conditions used (vapor phase, relatively low reaction temperature: $260^{\circ} \mathrm{C}$ in the present study and $210^{\circ} \mathrm{C}$ in the work of Mitta et al.).

The reaction route to hydroxyacetone involves the formation of an enol as proposed by different authors on copper based catalysts [54]. The important role of copper oxidation state was indicated by Pinheiro et al. [55] and Xiao et al. [56]. The weak acid sites, $\mathrm{Cu}^{2+}$ cannot be responsible for dehydration [57], as confirmed by the results we obtained in the present paper. It is also clear that metallic copper is an active site for dehydration of glycerol to HA, dehydrogenation at the surface of $\mathrm{Cu}^{\circ}$ occurs first and the formation of $\mathrm{Cu}$-alkoxide species is proposed $[53,58,59]$. Over $\mathrm{Cu}^{+}$, the reaction mechanism is more difficult to establish, different authors showed that $\mathrm{Cu}^{+}$is active for dehydration of glycerol $[56,57]$ which corroborates our results. Xiao et al. [56] indicate that it is not possible to state if $\mathrm{Cu}^{+}$is active "per se" or if it is due to the Lewis acid properties of $\mathrm{Cu}^{+}$.

So according to the studies published and to the results we obtained two different mechanisms are proposed: one based on Lewis acid properties of $\mathrm{Cu}^{+}$and the other one based on the oxidation state of copper: $\mathrm{Cu}^{+}$.

The involvement of the Lewis acid sites of $\mathrm{Cu}^{+}$can be proposed according to the mechanism of Alhanash et al. (Fig.9 a). In the second mechanism, we propose a homolytic C-H bond 
dissociation (similar to the one proposed on metallic copper, Fig.9 b). The C-H bond rupture at the surface of $\mathrm{Cu}^{+}$is supported by the work of Wang et al. [60], who performed DFT calculations to explain the dehydrogenation of cyclohexanol to cyclohexanone. The authors proved that the hydrogen bonded to carbon is more easily removed on $\mathrm{Cu}^{+}$than on $\mathrm{Cu}^{\circ}$, so a homolytic rupture of the $\mathrm{C}-\mathrm{H}$ bond in glycerol by $\mathrm{Cu}^{+}$is proposed.

In order to support the mechanism, theoretical calculations were performed and compared with the results of Nimlos [61] who established the more probable intermediate species in glycerol dehydration to HA. The calculations were performed at the B3LYP/6-31+G(d,p) level. Transition states took into consideration were radical intermediate of glycerol as shown in Fig. 9b. All computed energies of the mechanism compounds are Gibbs free energies at 534.15 K. Calculations were performed with the Gaussian09 code.

The relative energies of the transition states involved in the two mechanisms are 70.9 and 73.2 $\mathrm{kcal} / \mathrm{mol}$ for mechanism 9a) and 9b) respectively (Fig. 10). Such high energy barriers indicate that these reactions are only likely to occur at high temperatures and under pyrolysis conditions. The values obtained, are in the same order indicating that the formation of intermediate species in the mechanism we propose are favorable in our experimental conditions $\left(\mathrm{T}=260^{\circ} \mathrm{C}\right)$.

Shortcomings of the simulation held should be highlighted, in our case we didn't take into consideration the "Transition State" theory as we considered each step of the mechanism as independent reactions. Additionally, the surface of the catalyst wasn't taken into consideration. This simplification hindered essential details about sorption and stabilization of glycerol on the surface.

Further studies on the theoretical and experimental level should be held on the role of the copper catalyst, and we consider that the discussion on the mechanism is still an open issue. 
A low catalytic activity towards $\mathrm{HA}$ formation is observed with $\mathrm{Cu}-\mathrm{MgO}$ and $\mathrm{Cu}-\mathrm{MgF}(\mathrm{OH})$, which can result from low amount (or absence) of $\mathrm{Cu}^{1+}$ at the surface of the support and high amount of basic sites which probably favors the occurrence of side reactions giving byproducts such as acids, aldehydes, aromatic compounds, glycerol oligomers [62]... and also coke as evidenced by TGA analysis (figure 11), as discussed below.

\section{Characterization of the catalysts after reaction}

After catalytic tests, the crystalline structure of the supports is retained (Fig. 1) showing the good stability of the magnesium oxide (hydroxide) fluoride materials under our experimental conditions, confirming their potential as support. The peaks corresponding to copper oxides disappear and the formation of metallic copper is observed on $\mathrm{Cu}-\mathrm{MgF}(\mathrm{OH})$ and $\mathrm{Cu}-\mathrm{MgO}$. This result can be explained by the reduction properties of glycerol according to Jin et al. [63].

On the contrary, $\mathrm{Cu}_{2} \mathrm{O}$ is always observed on $\mathrm{Cu}-\mathrm{MgF}_{2}$ even if the formation of $\mathrm{Cu}^{\circ}$ cannot be totally excluded due to the peaks with very low intensity at $43.3^{\circ}$ (shoulder) and $50.4^{\circ}$ (figure 1). Moreover, the peaks of $\mathrm{Cu}_{2} \mathrm{O}$ are broadened after reaction reflecting a decrease of the crystallites size probably due to a partial reduction of the oxide. Nevertheless, in our experimental conditions, $\mathrm{MgF}_{2}$ support seems to stabilize the copper oxide at a degree of oxidation $+\mathrm{I}$ while metallic copper is obtained over the two other supports.

As observed in Table 1, the specific surface areas of $\mathrm{Cu}-\mathrm{MgF}(\mathrm{OH})$ and $\mathrm{Cu}-\mathrm{MgO}$ decrease drastically (from 165 to $17 \mathrm{~m}^{2} \cdot \mathrm{g}^{-1}$ and from 68 to $37 \mathrm{~m}^{2} \cdot \mathrm{g}^{-1}$ respectively) after catalytic tests whereas the specific surface area remains comparatively stable for $\mathrm{Cu}-\mathrm{MgF}_{2}$. This is in agreement with the XRD pattern since no change is observed after the catalytic test for $\mathrm{Cu}$ $\mathrm{MgF}_{2}$. 
Thermal analyses (TGA) were performed on the catalysts before and after catalytic tests until $900^{\circ} \mathrm{C}$ (figure 11 ). As observed, a very weak weight loss $(2.5 \%)$ is observed on $\mathrm{Cu}-\mathrm{MgF}_{2}$ corresponding to the removal of physisorbed water and/or remaining organic compounds derived from the sol-gel synthesis process. This weight loss is higher on $\mathrm{Cu}-\mathrm{MgO}(4.7 \%)$ and especially on $\mathrm{Cu}-\mathrm{MgF}(\mathrm{OH})(14.6 \%)$. In addition to physisorbed water and remaining organic compounds, these weight losses between 300 and $400{ }^{\circ} \mathrm{C}$ for $\mathrm{Cu}-\mathrm{MgO}$ and between 400 and $500{ }^{\circ} \mathrm{C}$ for $\mathrm{Cu}-\mathrm{MgF}(\mathrm{OH})$ can be explained by the dehydroxylation of magnesium hydroxide. This is in agreement with the XRD pattern of $\mathrm{Cu}-\mathrm{MgF}(\mathrm{OH})$ (figure 1) showing the presence of magnesium hydroxide. Moreover, the XRD pattern of $\mathrm{Cu}-\mathrm{MgF}(\mathrm{OH})$ after TGA (not shown) corresponds to a mixture of $\mathrm{MgO}$ and $\mathrm{MgF}_{2}$ confirming this dehydroxylation. Even if only $\mathrm{MgO}$ is observed for $\mathrm{Cu}-\mathrm{MgO}$ (figure 1), the presence of a small amount of hydroxyl group cannot be totally excluded. After catalytic tests, the weight losses are higher whatever the catalysts. This is due to the formation of "coke" on the catalyst during the transformation of glycerol, removed by oxidation during the thermal analysis under dry air. The deposition of coke is clearly limited on $\mathrm{Cu}-\mathrm{MgF}_{2}$ since the difference of weight loss before and after the catalytic test is only of $2.5 \%$. By contrast, the amount of coke is clearly higher for the two other catalysts with a difference of weight loss of $24 \%$ for $\mathrm{Cu}-\mathrm{MgF}(\mathrm{OH})$ and $12.9 \%$ for $\mathrm{Cu}-$ $\mathrm{MgO}$. These results are consistent with the $\mathrm{S}_{\mathrm{BET}}$ which decreases after reaction for both catalysts while $\mathrm{S}_{\mathrm{BET}}$ of $\mathrm{Cu}-\mathrm{MgF}_{2}$ remains stable as discussed above. Based on the assumption that basic sites play a role on the coke formation by side-reactions as discussed above, the amount of coke is also in accordance with basic properties, higher the basicity (figure 4), higher the amount of coke.

Thus, $\mathrm{Cu}-\mathrm{MgF}_{2}$ is a more suitable catalyst than the two other catalysts to avoid decrease of specific surface area, formation of coke and deactivation. Long terms experiment should be performed to confirm the catalytic stability of the catalyst. 


\section{Conclusions}

The dehydration of glycerol to hydroxyacetone was successfully investigated over copper supported on magnesium oxide (hydroxide) fluoride catalysts, in gas phase in the presence of water at $260^{\circ} \mathrm{C}$. The catalysts were prepared according to a sol-gel method following by a copper impregnation step and led to different $\mathrm{CuO}_{\mathrm{x}}$-magnesium oxide (hydroxide) fluoride composites with different crystallinities, copper oxidation state and tunable acid-base properties. Among the different studied catalysts, $\mathrm{Cu}-\mathrm{MgF}_{2}$ is the most interesting since $\mathrm{Cu}^{+}$, the active site, is stabilized at the surface of the support, whereas no (or little) coke formation during time on stream is observed contrary to $\mathrm{Cu}-\mathrm{MgO}$ and $\mathrm{Cu}$ $\mathrm{Mg}(\mathrm{OH}) \mathrm{F}$ catalysts. Moreover, this catalyst led to the best catalytic activity and stability, with a glycerol conversion reaching $82 \%$ and a yield in hydroxyacetone of $45.5 \%$ after one hour of reaction. $\mathrm{Cu}-\mathrm{MgF}_{2}$ is much more active than $\mathrm{La}_{2} \mathrm{CuO}_{4}(26.7 \%$ yield in $\mathrm{HA})$ which exhibited a high activity towards HA synthesis but in the absence of water. The results obtained in the present study showed that the basic properties of the catalysts did not governed the dehydration of glycerol into HA. The best catalyst $\left(\mathrm{Cu}-\mathrm{MgF}_{2}\right)$ is the one possessing Lewis acidity and stabilizing copper at +1 oxidation state.

Thanks to their tunable properties (acid/base, specific surface area, metal/support interaction), this work confirms the potential of magnesium oxide (hydroxide) fluoride as support for different heterogeneous catalytic processes as already observed for other reactions. In another way, it offers new opportunities for the production of hydroxyacetone from glycerol with an environmentally friendly process.

\section{References}

[1] A. Behr, J. Eilting, K. Irawadi, J. Leschinski, F. Lindner, Green Chem., 10 (2008) 13-30 
[2] D. Sun, Y. Yamada, S. Sato, W. Ueda, Appl. Catal. B: Env., 193 (2016) 75-92

[3] D. Roy, B. Subramaniam, R. V.Chaudhari, Catal. Today, 156 (2010) 31-37

[4] V. Montes, M. Checa, A. Marinas, M. Boutonnet, J.M. Marinas, F.J. Urbano, S. Järas, C. Pinel, Catal. Today, 223, (2014) 129-137

[5] M. Massa, A. Andersson, E. Finocchio, G. Busca, J Catal. 307 (2013) 170-184

[6] J. Deleplanque, J.-L. Dubois, J.-F. Devaux, W. Ueda, Catal. Today, 157 (2010) 351-358

[7] A. Talebian-Kiakalaieh, N. Aishah Saidina Amin, Renewable Energy, 114 (2017) 794-804

[8] T. Ma, J. Ding, R. Shao, W. Xu, Z. Yun, Chem. Eng. J., 316 (2017) 797-806

[9] M. E Doukkali, A. Iriondo, J.F. Cambra, I. Gandarias, L. Jalowiecki-Duhamel, F. Dumeignil, P.L. Arias, Appl. Catal. A: Gen. 472 (2014) 80-91

[10] M. Dalil, D. Carnevali, M. Edake, A. Auroux, J.L. Dubois, G.S. Patience, J. Mol. Cat. A: Chem., 421 (2016) 146-155

[11] L. H. Vieira, K.T.G. Carvalho, E. A. Urquieta-González, S . H. Pulcinelli, C. V. Santilli, L. Martins, J. Mol. Cat. A: Chem., 422 (2016) 148-157

[12] W. Suprun, M. Lutecki, H. Papp, Chem. Eng. Tech. 33 (2010) 1-7

[13] A. Alhanash, E. F. Kozhevnikova, I. V. Kozhevnikov, Appl. Catal. A: Gen., 378 (2010) $11-18$

[14] C.L. Lima, S. J.S. Vasconcelos, J.M. Filho, B. C. Neto, M.G.C. Rocha, P. Bargiela, A. C. Oliveira, Appl. Catal. A: Gen 399 (2011) 50-62

[15] P. Lauriol-Garbey, J.M.M. Millet, S. Loridant, V. Bellière-Baca, P. Rey, J. Catal. 281 (2011) 362-370

[16] A. Kinage, P. Upare, P. Kasinathan, Y. Kyu Hwang, J.S. Chang, Catal. Comm. 11 (2010) 620-623

[17] C. Montassier, J.C. Ménézo, L.C. Hoang, C. Renaud, J. Barbier, J. Mol. Cat. 70 (1991) 99-110

[18] S. Xia, R. Nie, X. Lu , L.Wang, P. Chen, Z. Hou, J. Catal. 296 (2012)1-11

[19] D. Roy, B. Subramaniam, R. V. Chaudhari, ACS Catal. 1 (2011) 548-551

[20] E. Kemnitz, Catal. Sci. Technol. 5 (2015), 786-806

[21] S. Célérier F. Richard, Catal. Commun. 67 (2015) 26-30

[22] M. Wojciechowska, W. Przystajko, M. Zielinski, Catal. Today 119 (2007) 338-341

[23] M. Wojciechowska, M. Zielinski, M. Pietrowski, Catal. Today 90 (2004) 35-38 
[24] A. Negoi, S. Wuttke, E. Kemnitz, D. Macovei, V. I. Parvulescu, C. M. Teodorescu, S. M. Coman, Angew. Chem. Int. Ed. 49 (2010) ) $8134-8138$

[25] F. Richard, S. Célérier, M. Vilette, J. D. Comparot, V. Montouillout, Appl. Catal. B 152153 (2014) 241-249

[26] I. Agirrezabal-Telleria, F. Hemmann, C. Jäger, P.L. Arias, E. Kemnitz, J. Catal. 305 (2013) 81-91

[27] M. Zielinski, M. Pietrowski, A. Kiderys, M. Kot, E. Alwin, J. Fluor. Chem. 195 (2017) $18-25$

[28] M. Wojciechowska, M. Zielinski, M. Pietrowski, J. Fluor. Chem. 120 (2003) 1-11

[29] S. Wuttke, S. M. Coman, G. Scholz, H. Kirmse, A. Vimont, M. Daturi, S. L. M. Schroeder, E. Kemnitz, Chem. Eur. J. 14 (2008) 11488 - 11499

[30] E. Kemnitz, S. Wuttke, S. M. Coman, Eur. J. Inor. Chem., (2011) 4773-4794

[31] M. Wojciechowska, A. Wajnert, I. Tomska-Foralewska, M. Zielinski, B. Czajka, Catal Lett 128 (2009) 77-82

[32] I. Tomska-Foralewska, M. Zielinski, M. Pietrowski, W. Przystajko, M. Wojciechowska, Catal. Today 176 (2011) 263-266

[33] M. Zielinski, I. Tomska-Foralewska, M. Pietrowski, W. Przystajko, M. Wojciechowska, Catal. Today 191 (2012) 75-78

[34] M. Zielinski, A. Kiderys, M. Pietrowski, I. Tomska-Foralewska, M. Wojciechowska, Catal. Commun. 76 (2016) 54-57

[35] M. Bonarowska, M. Wojciechowska, M. Zielinski, A. Kiderys, M. Zielinski, P. Winiarek, Z. Karpinski, Molecules 21 (2016) 1620

[36] G. Scholz, C. Stosiek, M. Feist, E. Kemnitz, Eur. J. of Inorg. Chem. 14 (2012) $2337-$ 2340

[37] S. Wuttke, S. M. Coman, J. Kroehnert, F. C. Jentoft, E. Kemnitz, Catal. Today 152 (2010) 2-10

[38] H. A. Prescott, Z. J. Li, E. Kemnitz, J. Deutsch, H. Lieske, J. Mater. Chem. 15 (2005) 4616-4628

[39] M. Velasquez, A. Santamaria, C. Batiot-Dupeyrat, Appl. Catal. B: Env, 160-161 (2014) 606-613

[40] H. Mitta, P. Kumar Seelam, S. Ojala, R. L. Keiski, P. Balla, Appl. Catal. A, General 550 (2018) 308-319

[41] I. Popescu, N. Tanchoux, D. Tichit, I.C. Marcu, Appl. Catal. A: Gen 538 (2017) 81-90

[42] K.H.P. Reddy, Y.W. Suh, N. Anand, B.D. Raju, K. S. Rama Rao, Catal. Com. 95 (2017)21-25 
[43] M. Jablonska, L. Chmielarz, A. Wegrzyn, K. Guzik, Z. Piwowarska, S. Witowski, R.I. Walton, P.W. Dunne, F. Kovanda, J. Therm. Anal. Calorim. 114 (2013) 731-747

[44] Y. Wang, X. Guo, M. Lu, Z. Zhai, Y. Wang, X. Guo, Chinese Journal of Catalysis 38 (2017) 658-664

[45] C.S. Polster, H. Nair, C.D. Baertsh, J. Catal. 266 (2009) 308-319

[46] Y. Liu, Z. Wang, W. Huang, Appl. Surf. Sci. 389 (2016) 760-767

[47] C.S. Chen, T.C. Chen, C.C. Chen, Y.T. Lai, J.H. You, T.M. Chou, C.H. Chen, J.F. Lee, Langmuir, 28 (2012) 9996-10006

[48] C. Liu, X. Guo, Q. Guo, D. Mao, J. Yu, G. Lu, J. Mol. Cat. A: Chemical 425 (2016) 8693

[49] M.C. Biesinger, L.W.M. Lau, A.R. Gerson, R.S.C. Smart, Appl. Surf. Sci. 257 (2010) $887-898$

[50] Ray L. Frost, Yunfei Xi, Barry J. Wood, Thermochimica Acta 545 (2012) 157- 162

[51] D. C. Carvalho, L. G. Pinheiroa, A. Campos, E. R.C. Millet, F. F. de Sousac, J. M. Filhoc, G. D. Saraivac, E. C. da Silva Filhod, M. G. Fonsecae, A. C. Oliveira, Appl. Catal. A: Gen 471 (2014) 39-49

[52] S. Sato, M. Akiyama, R. Takahashi, T. Hara, K. Inui, M. Yokota, Appl. Catal. A : Gen 347 (2008) 186-191

[53] D. Stosic, S. Bennici, S. Sirotin, C. Calais, J.L. Couturier, J.L. Dubois, A. Travert, A. Auroux, Appl. Catal. A: Gen., 447-448 (2012) 124-134

[54] B. Katryniok, S. Paul, V. Bellière-Baca, P. Reye and F. Dumeignil, Green Chem., 12 (2010) 2079-2098

[55] T.Pinheiro Braga, N. essayem, A. Valentini, J. Therm. Anal. Calorim. 129 (2017) 65-74

[56] Z. Xiao, X. Wang, J. Xiu, Y. Wang, C.T. Williams, C. Liang, Catal. Today, 234 (2014) 200-207

[57] P.A. Torresi, V.K. Diez, P.J. Luggren, J.I. Di Cosimo, Appl. Catalysis A: general 458 (2013) 119-129

[58] A.J. Gellman, M.T. Buelow, S.C. Street, T.H. Morton, J. Phys. Chem. A 104 (2000) 2476

[59] R.M. Rioux, M.A. Vannice, J. Catal. 216 (2003) 362-376

[60] Z. Wang, X. Liu, R. P. Hu, Surface Science 640 (2015) 181-189

[61] M.R. Nimlos, S.J. Blanksby, X. Qian, M.E. Himmel, D.K. Johnson, J.Phys. Chem. A 110 (2006) 6145-6156 
[62] F.A.A. Barros, H.S.A. de Sousa, A . C. Oliviera, M.C. Junior, J.M. Filho, B.C. Viana, A.C. Oliveira, Catal. Today, 212 (2013) 127-136

[63] F. Jin, X. Zeng, Z. Jing, H. Enomoto, Ind. Eng. Chem. Res. 51 (2012) 9921-9937 
Table 1 Textural properties of the catalysts

\begin{tabular}{|c|c|c|c|c|c|c|}
\hline Support & $\underset{\left(\mathbf{m}^{2} \mathbf{g}^{-1}\right)}{\mathbf{S}_{\text {BET }}}$ & Catalyst & $\begin{array}{c}\mathbf{S}_{\text {BET }} \\
\left(\mathbf{m}^{2} \mathbf{g}^{-1}\right)\end{array}$ & $\begin{array}{c}\mathrm{S}_{\text {BET }}\left(\mathrm{m}^{2} \mathrm{~g}^{-1}\right) \\
\text { after } \\
\text { catalytic test }\end{array}$ & $\begin{array}{l}\text { Weight content } \\
\text { of } \mathrm{Cu}(\%)^{1}\end{array}$ & $\begin{array}{c}\text { Lewis } \\
\text { Acidity } \\
\left.(\mu \mathrm{mol} \mathrm{g})^{-1}\right)\end{array}$ \\
\hline $\mathrm{MgO}$ & 227 & $\mathrm{Cu}-\mathrm{MgO}$ & 68 & 37 & 4.7 & $<10$ \\
\hline $\mathrm{MgF}(\mathrm{OH})$ & 270 & $\mathrm{Cu}-\mathrm{MgF}(\mathrm{OH})$ & 165 & 17 & 4.6 & $<10$ \\
\hline $\mathrm{MgF}_{2}$ & 33 & $\mathrm{Cu}-\mathrm{MgF}_{2}$ & 36 & 27 & 4.8 & 50 \\
\hline & & $\mathrm{La}_{2} \mathrm{CuO}_{4}$ & 2.2 & n.d. & & \\
\hline
\end{tabular}

determined from ICP OES analysis

Table 2 Hydrogen consumption and $\mathrm{Cu}^{2+} / \mathrm{Cu}^{+}$concentration determined from TPR analysis.

\begin{tabular}{|c|c|c|c|c|c|}
\hline \multirow{2}{*}{ Catalyst } & \multicolumn{3}{|c|}{$\begin{array}{l}\mathrm{H}_{2} \text { consumption for copper oxide } \\
\text { reduction }(\mathrm{mL} \mathrm{STP} / \mathrm{g})( \pm 2 \%)\end{array}$} & \multicolumn{2}{|c|}{$\mathrm{Cu}(\%) * * *$} \\
\hline & a) $\mathrm{Cu}^{2+}$ & $\begin{array}{l}\text { ted* } \\
\text { b) } \mathrm{Cu}^{+}\end{array}$ & Determined $* *$ & $\mathrm{Cu}^{2+}$ & $\mathrm{Cu}^{+}$ \\
\hline $\mathrm{Cu}-\mathrm{MgO}$ & 21.5 & 10.7 & 20.5 & 91 & 9 \\
\hline $\mathrm{Cu}-\mathrm{MgF}(\mathrm{OH})$ & 19.5 & 9.8 & 16.3 & 67 & 33 \\
\hline $\mathrm{Cu}-\mathrm{MgF}_{2}$ & 20.3 & 10.2 & 12.7 & 25 & 75 \\
\hline
\end{tabular}

*Estimated: calculated from the nominal composition of the material according to the following reactions: a) $\mathrm{CuO}+\mathrm{H}_{2}=\mathrm{Cu}+\mathrm{H}_{2} \mathrm{O}$ and b) $\mathrm{Cu}_{2} \mathrm{O}+\mathrm{H}_{2}=2 \mathrm{Cu}+\mathrm{H}_{2} \mathrm{O}$

**Determined: obtained from $\mathrm{H}_{2}$-TPR profile

*** $\mathrm{Cu}^{2+}$ and $\mathrm{Cu}^{+}$concentration (\%) estimated from the volume of $\mathrm{H}_{2}$ obtained by TPR 
Table $3 \mathrm{Cu} / \mathrm{Mg}$ atomic ratio

\begin{tabular}{cccc}
\hline Atomic ratio Cu/Mg & $\mathrm{Cu}-\mathrm{MgO}$ & $\mathrm{Cu}-\mathrm{MgF}(\mathrm{OH})$ & $\mathrm{Cu}-\mathrm{MgF}_{2}$ \\
\hline Bulk* $^{*}$ & 0.036 & 0.050 & 0.054 \\
\hline Surface** & 0.008 & 0.029 & 0.082 \\
& & & \\
* Calculated from ICP OES & & \\
** Calculated from XPS analysis & &
\end{tabular}


Figure 1. XRD patterns of (I and I') $\mathrm{Cu}-\mathrm{MgO}$, (II) $\mathrm{Cu}-\mathrm{MgF}(\mathrm{OH})$ and (III) $\mathrm{Cu}-\mathrm{MgF}_{2}$ after synthesis (a) and after catalytic test (b).

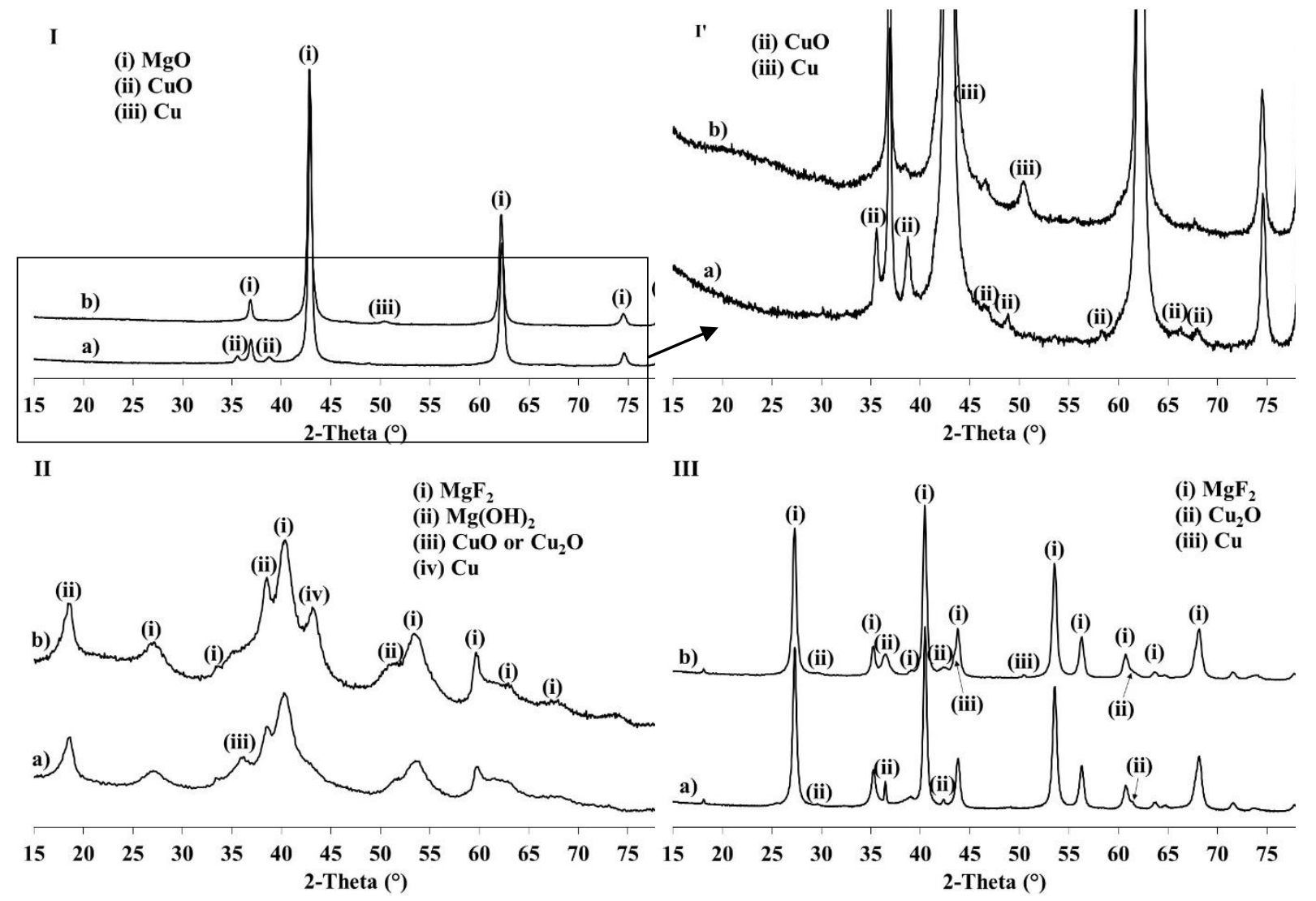


Figure 2: TPR analysis

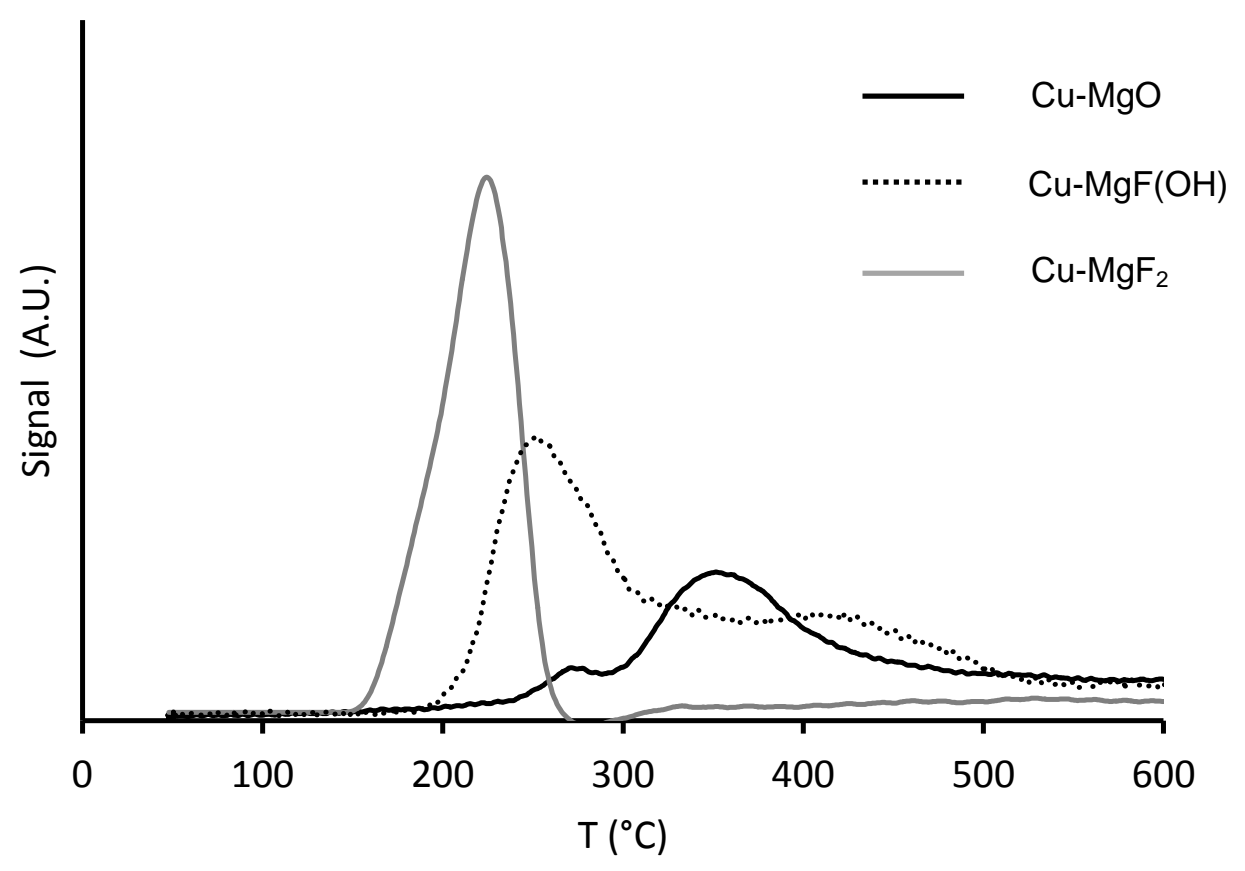


Figure 3: Isotherms of $\mathrm{CO}_{2}$ adsorption on $\mathrm{Cu}$-magnesium fluoride catalysts




Figure 4: $\mathrm{CO}_{2}$ monolayer content versus surface area for $\mathrm{Cu}-\mathrm{MgO}, \mathrm{Cu}-\mathrm{MgF}(\mathrm{OH})$ and $\mathrm{Cu}-$ $\mathrm{MgF}_{2}$

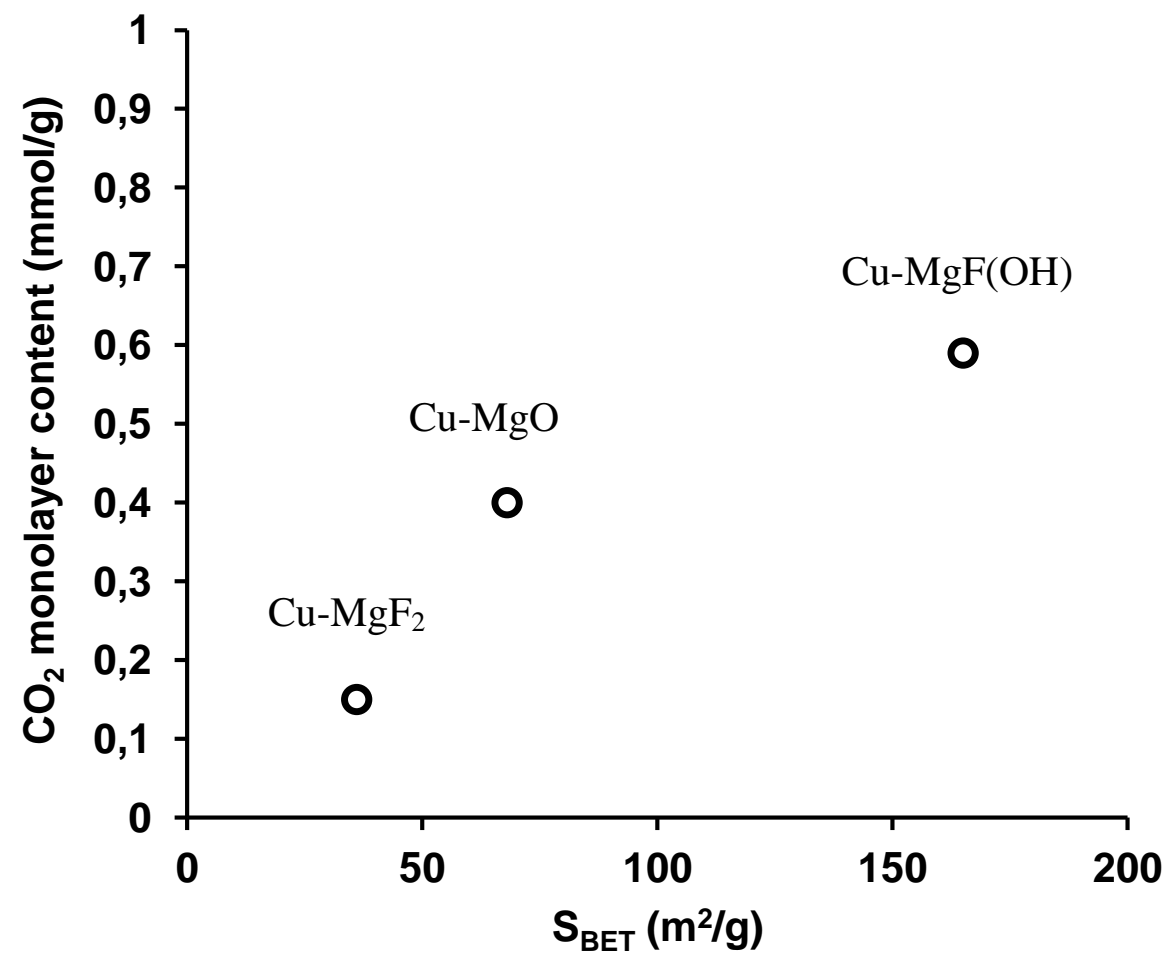


Figure 5: XPS analysis of $\mathrm{Cu}-\mathrm{MgO}, \mathrm{Cu}-\mathrm{MgFOH}$ and $\mathrm{Cu}-\mathrm{MgF}_{2}$

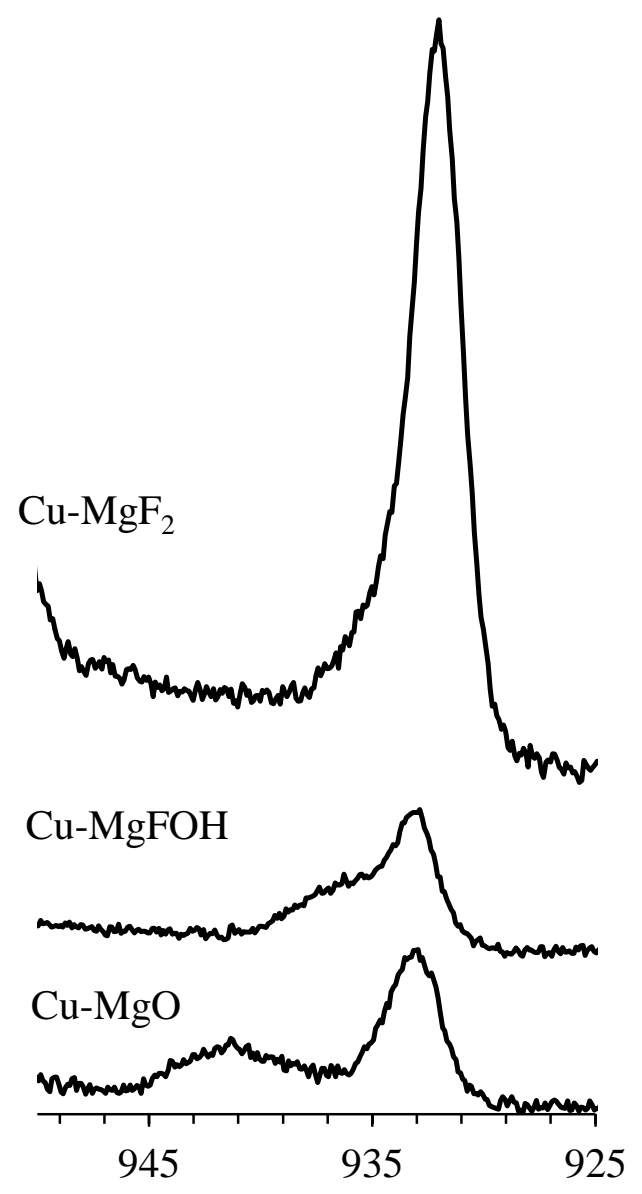

Binding energy $(\mathrm{eV})$ 
Figure 6: Glycerol conversion as a function of reaction time and catalyst




Figure 7: Yield in HA as a function of reaction time and catalyst

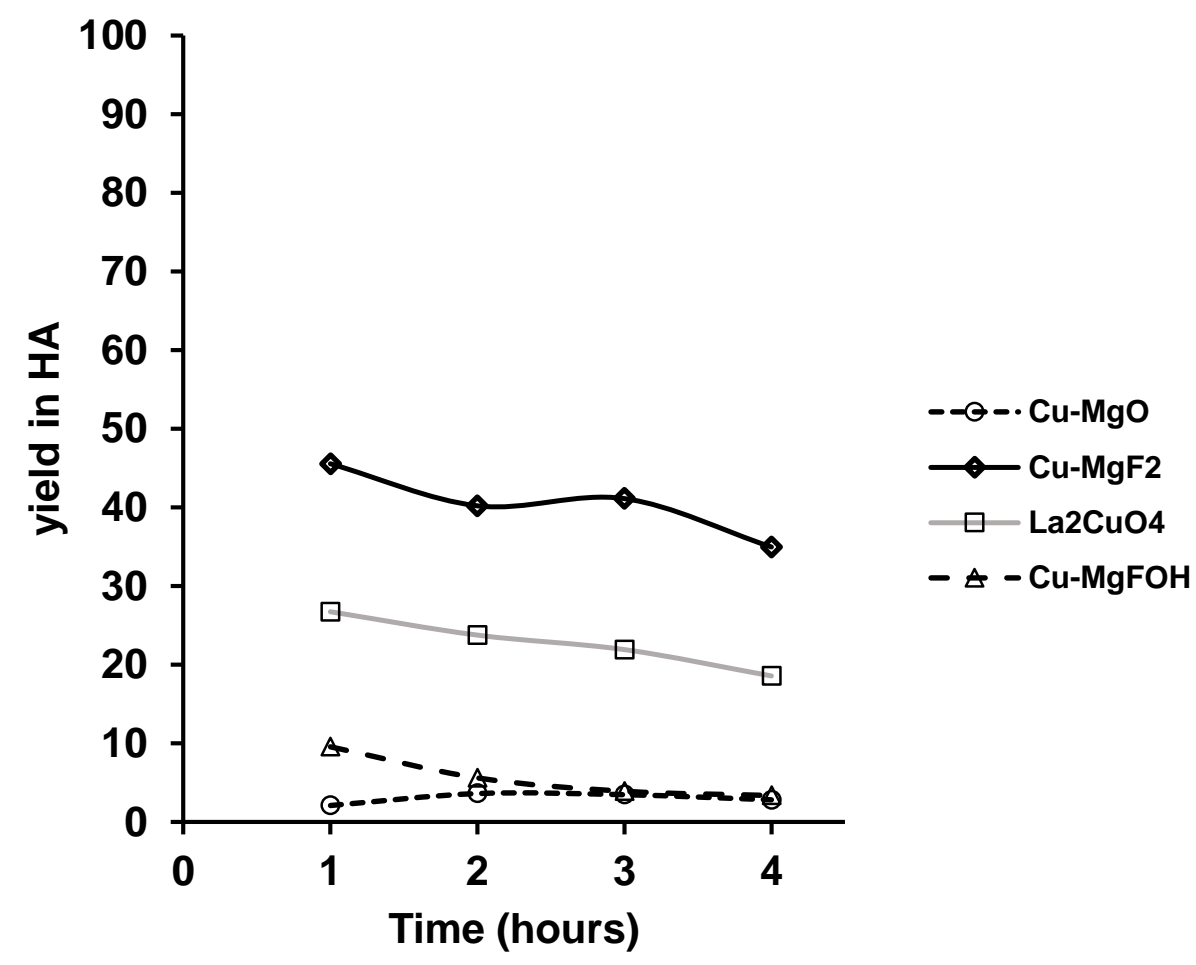


Figure 8: Hydroxyacetone yield after 1 hour of reaction as function of acid sites density and $\mathrm{Cu}^{+1}$ concentration




Figure 9: Proposed reaction routes of hydroxyacetone formation from glycerol on $\mathrm{Cu}-\mathrm{MgF}_{2}$

(a) Lewis acid mechanism proposed by Alhanash; (b) homolytic dissociation mechanism

(a)

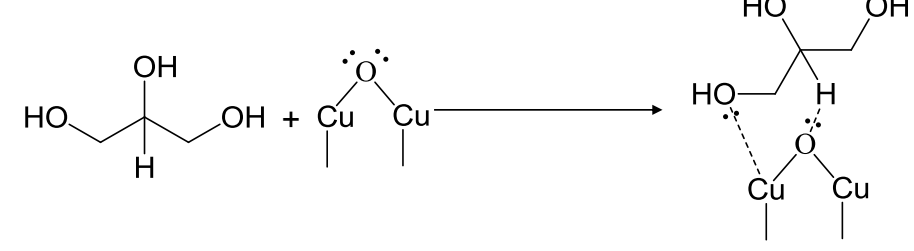

(b)

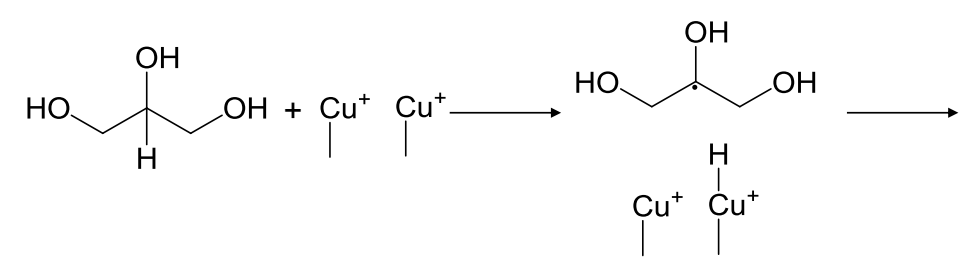<smiles>CC(=O)CO</smiles><smiles>C=C(O)CO</smiles><smiles>C[CH-]O[C-](C)C</smiles> 
Figure 10: Potential energy plot for the reaction of neutral glycerol to form acetol (red: Nimos et al. [61], black: calculated Gibbs energy for mechanism b)

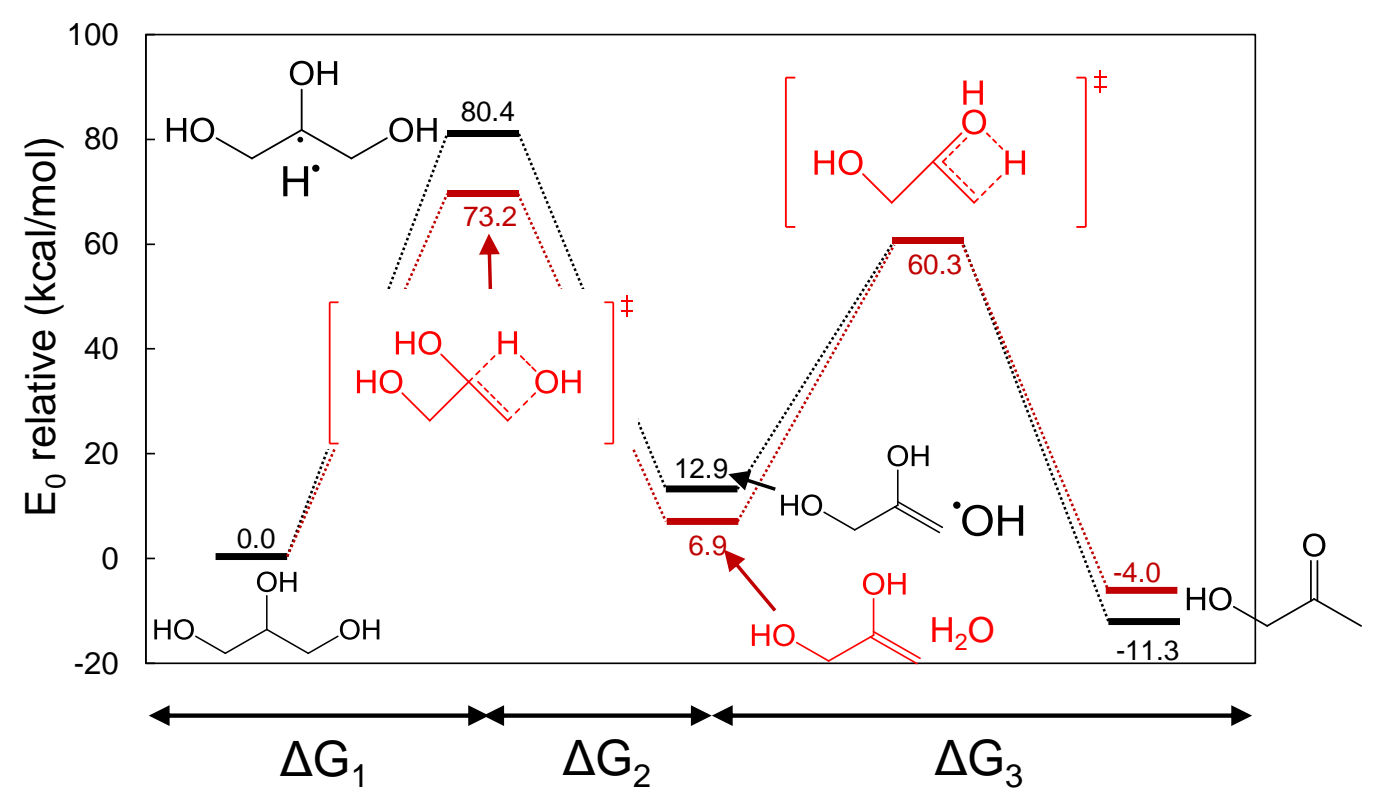


Figure 11: TGA curves of a) $\mathrm{Cu}-\mathrm{MgO}$, b) $\mathrm{Cu}-\mathrm{MgF}(\mathrm{OH})$ and c) $\mathrm{Cu}-\mathrm{MgF}_{2}$ before (solid line) and after (dotted line) catalytic tests.
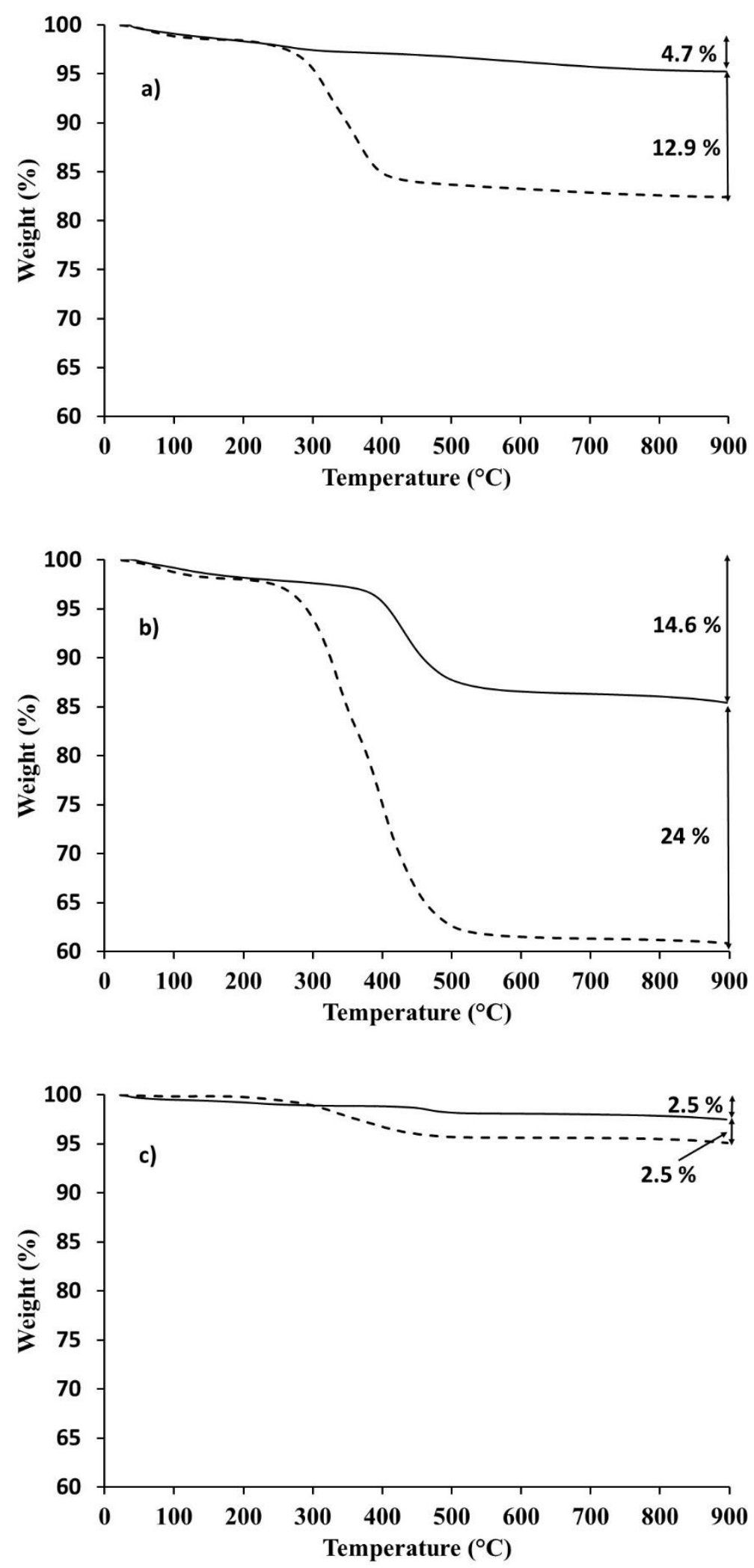